811.163.41'35 https://doi.org/10.18485/sj.2019.24.1.37

ГОРАН Н. ЗЕЉИЪ ${ }^{*}$

Универзитет у Београду

Учитељски факултет
Оригинални научни рад Примљен: 27. 11. 2018. Прихваћен: 15. 01. 2019.

\title{
ГЕНИТИВНИ ЗНАК ИЛИ ЗНАК ДУЖИНЕ
}

У раду аутор анализира дистрибутивна ограничења употребе генитивног знака и испитује оправданост терминолошког двојства који произилази паралелном употребом овог термина и термина знак дужине. Анализом су обухваћени сви релевантни нормативни приручници, почев од Белићевог правописа, преко Матичиних правописних приручника до Дешићевог и Симићевог правописа. Уз то представљен је и велики број примера који одступају од актуелне норме. Предложено је и решење по коме би правило било да се овај знак употребљава само онда када не разликујемо облике генитива множине и неки облик једнине.

Кључне речи: генитивни знак, знак дужине, правопис, граматика

\section{1. УВОД}

1. У правописним приручницима генитивни знак (који је представљен само графички, без назива) појавио се још у Српском правопису Стеве Чутурила (1884). Овим угластим знаком означено је сажимање самогласника „, ао у дугачко $\hat{o}$ а у јужном говору у дугачко $\hat{a}$ " (Чутурило 1884: 10). Чутурило даље наглашава да у књижевном језику ово сажимање није допуштено. Још тада Чутурило истиче и случајеве у којима до сажимања долази, па тако наводи

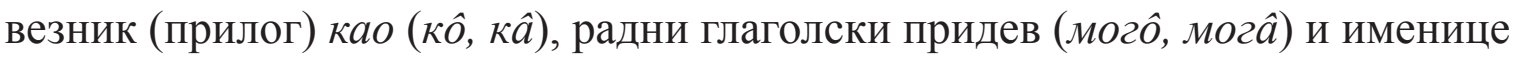

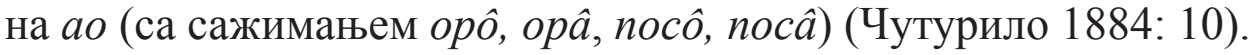

*goran.zeljic@uf.bg.ac.rs 
2. Белићевим правописом (Белић 1923: 153; 1952: 106) установљено је да овај знак треба писати на крају речи када је она у генитиву множине и када би требало нагласити разлику у односу на други облик са истим наставком и то илуструје именицама жена (генитив множине има исти наставак као и номинатив једнине) и облак (има једнаке наставке за генитив једнине и генитив множине). У другим случајевима Белић предлаже коришћење акцената дајући пример Jа сам са̂м био my, са примером који је у важећој норми дат са генитивним знаком. Сажимање самогласника дато је у делу посвећеном апострофу (Белић 1923: 153), који прати напомена да га не треба користити у овом случају, а само сажимање представљено је примерима који су обележени на различите начине. У првом случају дат је прилог као, чији сажети облик је представљен уз генитивни знак (кô), а у другом сажети облик радног глаголског придева у мушком роду са акцентом и дужином (рёко̄).

3. Систематизовање правила о употреби генитивног знака на Белићевим основама дато је у Матичиним правописима и креће се, како је то Белић поставио, пре свега у два смера - као истицање обличке разлике како једне речи (именице), тако и између двеју речи различитих граматичких врста (обележава се разлика између генитива једнине и множине, те везника да и презента глагола дати у 3. л. јд. и енкл. облика глагола јесам (през.) и заменичког придева сам) и за бележење сажимања самогласника. У првом случају, заједничко за Матичине правописе јесте да генитивни знак остаје разликовни знак између двеју речи различите врсте или облика, пре свега генитива једнине и множине ${ }^{1}$ (П60: 124; П93: 293; П2010: 140). Међутим, у приручнику из 1960. године заменички придев сам дат је с дугосилазним акцентом да би се разликовао од енклитичког облика пом. глагола јесам ( П60: 123). Такође, за обележавање сажимања гласова постоје разлике у стандарду, а решења су у вези и са апострофом. Тако је у П60 и П2010 сажимање самогласника у радном глаголском придеву истакнуто (П60:123; П2010: 139), а у П93 (П93: 293) сажимање је сведено на облике везника (прилога) као (ко) и именице типа мисао (мисо). У П60 оно се обележава знаком дужине (чеко̄) или изостављањем било којег знака (чеко), у П2010 знаком дужине али угластим (дошо) који се такође факултативно користи и коме се даје предност у односу на коришћење апострофа (П93: 293).

${ }^{1}$ У школском правописном приручнику Јована Јерковића и Душанке Вујовић (2012), у правописном речнику овим знаком истиче се и разлика прво између генитива једнине и множине, затим између номинатива једнине и генитива множине, те између датива једнине и генитива множине, нпр. битанга, ген. мн. -нгиิ/-нга̂ (Јерковић/Вујовић 2012:77). 


\section{2. ТЕРМИНОЛОГИЈА И ГРАФИЧКА РЕШЕЬА У ПРАВОПИСНОЈ И ГРАМАТИЧКОЈ ЛИТЕРАТУРИ}

1. Назив генитивни знак је правописни термин и преовладава у правописним приручницима ${ }^{2}$. У њима се, са функцијом да се овим знаком истакне да је реч у генитиву множине, а) почев од Белићевог, користи угласти циркумфлекс, нпр. школа без учитељ $\hat{a}$ (П2010: 140), те б) водоравна црта као акценатска дужина (дом̄̄) у П60.

Табела 1. Терминологија у правописној литератури

\begin{tabular}{|c|c|}
\hline Правописи & Термин \\
\hline Белић $1923 / 1952$ & знак \\
\hline П60 & $\begin{array}{c}\text { a) знак дужине }(\text { домо̄) } \\
\text { б) генитивни знак (nријатељь })\end{array}$ \\
\hline П93 & знак дужине/ генитивни знак \\
\hline Симић et al. 1993 & генитивни знак \\
\hline П2010 & знак дужине/ генитивни знак \\
\hline Дешић 2015 & генитивни знак/ знак дужине \\
\hline Симић 2016 & генитивни знак \\
\hline
\end{tabular}

2. У граматичким приручницима ова дужина вокала у генитиву множине бележи се а) као полукружни циркумфлекс, нпр. јёлеิнаิ (Даничић 1850: 6; Новаковић 1902: 150 - шӓраิнаิ) и то у старијим граматикама, односно б)

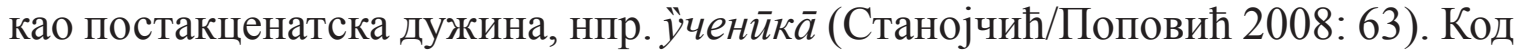
Пипера и Клајна налазимо знак дужине у облику циркумфлекса на финалном самогласнику (нпр. Пипер/Клајн 2013: 78; читање романа̂) за разликовање генитива множине од генитива једнине, чиме се успоставља и (графичка) разлика у односу на постакценатску дужину (нпр. ген. мн. слоิва̄).

\footnotetext{
${ }^{2}$ Под тим називом уводи се и у наставну праксу у осмом разреду основне школе (Наставни програм за осми разред основног образовања и васпитања, Завод за унапређивање образовања и васпитања, http://zuov.gov.rs/nastavni-planovi-i-programi).
} 
Табела 2. Графичко решење и терминологија

\begin{tabular}{|c|c|c|c|c|}
\hline $\begin{array}{c}\text { графичко } \\
\text { решење }\end{array}$ & полукружни & \multicolumn{2}{|c|}{ права црта } & угласти \\
\hline \multirow{2}{*}{ термин } & \multicolumn{2}{|c|}{ прозодијски знак } & \multicolumn{2}{|c|}{ правописни знак } \\
\hline & знак дужине & $\begin{array}{c}\text { знак дужине (постак- } \\
\text { ценатска дужина) }\end{array}$ & знак дужине & $\begin{array}{c}\text { знак дужине/ } \\
\text { генитивни знак }\end{array}$ \\
\hline пример & јёлеิнаิ & ӱченйкй & дошо̄ & учитељь \\
\hline функција & \multicolumn{2}{|c|}{ за истицање дужине гласа } & $\begin{array}{c}\text { за истицање сажимања } \\
\text { самогласника }\end{array}$ & $\begin{array}{c}\text { за истицање обличке разлике и } \\
\text { сажимања самогласника }\end{array}$ \\
\hline
\end{tabular}




\section{3. ДИСТРИБУТИВНА ОГРАНИЧЕЊА}

1. У анализираним правописима истичу се најчешће три случаја ${ }^{3}$ у којима се употребљава генитивни знак (П60: 124; П93: 293; П2010: 140; Дешић 2015: 191), и то за:

1. разликовање генитива множине од генитива једнине (или неког другог облика)

2. диференцирање подударних облика различитих граматичких врста (најчешће у непосредном суседству)

3. обележавање сажетих вокала (употребљава се необавезно; П2010: 139)

2. Кад је реч о првом случају, пођимо од граматичког аспекта. Видели смо да се генитив множине именица мушког и средњег рода гради се дугим вокалом $\bar{a}$ (Станојчић/Поповић 2008: 84). У промени именица типа учитељ, поље једино је дужина на финалном гласу дистинктивно обележје у односу на генитив једнине (нпр. Слушали смо савете професора: Слушали смо савете nрофесо̄pā.). У говору ови облици се много не разликују (Пипер/Клајн 2013: 78), док у писаном говору, да би се избегла двосмисленост, изнад финалног вокала у облику множине биће употребљен знак дужине (78; Клајн 2005: 57), односно генитивни знак (П2010: 140).

3. Док је први случај са становишта писане праксе потпуно јасан, у преостала два случаја није тако. Наиме, хомонимија се не мора обележавати само генитивним знаком, већ и акцентима (нпр. мо̀ра и мо́ра, бӥла и би́ла (пом. глагол), са́мо и сӓмо, код и коิ $\left.\partial^{4}\right)$, што, разуме се, остаје у оквирима стандарда, док код радног глаголског придева, али и код поредбеног везника, већ традиционално налазимо апостроф уместо генитивног знака као супстандардно решење (још од Белићевог времена). Додатни проблем је и то што је реч о знаку који се употребљава факултативно, тј. није обавезан.

4. Сва три случаја засведочена су у писаној пракси. Сажимање самогласника илустровано је само примерима са генитивним знаком, док су супстандардни облици дати у посебном делу.

${ }^{3}$ Поред обележавања имперфекта типа писа̂x у односу на аорист писах (у коме је самогласник $a$ кратак) и презента типа носиิ у односу на императив носи са кратким самогласником $u$ (П2010: 140).

${ }^{4}$ Једва се дисало у јари која је бйла из каменог тла (Ками 1989: 67). Била јој је неопходна неговатељица (32). Са́мо тело тражи да изађе на стазу и трчи (Мураками 2017: 114). Само што време испуњава своју дужност (114). Језичко знање подразумијева познавање самог система знакова за споразумијевање, који се у комуникологији назива коิд (па је то, онда, компетенција или познавање коิда) (Шипка 2011: 22). 


\section{1. Разликовање генитива множине од номинатива/генитива једнине}

Али што ми је непојмљиво и туђе, то је та досљедност, та истрајност у једном вјеровању, та статичност заноса̂ (Десница, 174). Партија која се зове политичка повијест народâ (238). Падне на конак код Грмића̂ у Бабиној Луци (Ненадовић, 30). Он, Павел Исакович, међутим, оће да га упозори да се они не плаше Гарсула̂, не једног, него ни сто (Црњански 2, 167). Толико имање Катића̂ они ће наследити (Ћосић, 67). Сваке ноћи петлови су у три наврата певали. Аћим се присећао разговора̂ с Вукашином (78). Где буде pупа̂, биће рупа̂, јел тако, кретену (Селенић, 95). По перонима Европе које више нема, уместо киоска̂ с пецивом и виршлама /.../ возове сада дочекују сакати људи (199). Савет Европе прогласио је 2001. Европском годином језика̄ (Бугарски 2005: 91). ${ }^{5}$

\section{2. Разликовање хомонима}

a) везник $\partial a$ : презент глагола дати у 3. л. јд. (обележен генитив. знаком)

\section{a1) оба облика}

Не, њега је охрабрила хајка која се дигла против нас, па је искористио тренутак да дâ одушке, која га изједа као шуга пса (Ненадић, 92). Одлучи да, стигавши дома, да̂ да му израде икону светога деспота Штиљановића, да остане и после његове смрти (Црњански 1, 133). Мати је пре тог спомињала господару Софри да да̂ Перу даље у школе, или да га да̂ гдегод на друго место у трговину (Игњатовић, 31). То ,још нешто” ваљда је нешто више него што треба и него што уопће може да се да̂ (Десница, 220).

\section{а2) само презент глагола дати у 3. л. јд.}

Дâ на знање госпођи Соки да ће сутра после ручка доћи Кречар (Игњатовић, 19). Сад отац ослови Ленку да и она седне, и да̂ донети „ауспруха” (22). Но, он опет не да̂ мира Кречару, пробудио га (41). То је дугачак пут, али се господар Софра не да̂ преломити (57). Он опет почне све грдити, и не да̂ коња водити (106).

\section{б) енкл. облик глагола јесам (през.) : заменички придев (обележен генитив. знаком)}

\section{б1) оба облика}

Зар не видиш да сам са̂м (Ћосић, 66). Са̂м сам. Па шта (Ћосић, 181). Овде у овој ноћи са̂м сам без жене, деце, пријатеља (Ненадић, 142).

\section{б2) само заменички придев (обележен генитив. знаком)}

Са̂м живот налази неслућена решења (Еренрајх Остојић 2000: 84). Али са̂м новац, на њихову велику жалост, био је по свему судећи немоћан да уклони оне баријере (93).

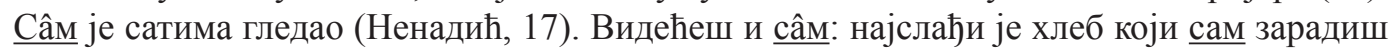
(36). Својим бродом âm крмани (43). Живео câm, као воденичко псето (Ћосић, 59).

${ }^{5}$ Као знак дужине (ā). У истој књизи и са угластим знаком (â): Она није ни пука врећа језика̂ (95). 
в) остало

Силовити дах водаิ међу морским змијама (Џојс 2016: 63). И види кладенац бистри и травни види поิд (Илић, 114). Они који су желели да чују бога долажаху у сумрак, паљаху ка̂д на огњишту (Пекић 1995: 179). Убићеш, као што су убијали сви они што су на̂с учили како да живимо (Атанацковић 2017: 26) ${ }^{6}$.

\section{3. Сажети вокали}

\section{a) радни глаголски придев}

a1) -оิ (од -ао, нпр. плакао, -ео, нпр. видео и -уо, нпр. куцзнуо)

Јер ја бих тад плако̂, ја бих вечно пплакоิ (Дучић, 6). Весело је цветоิ / Турчинак у њеном говору и смеху (45). Једног дана спази да је постоิ бео (300) Добро дошоิ, млађано Бугарче! (Ђурић, 116) Ето доље под градом Леђаном /изишо̂ је краљев заточниче (122). За ноћ буде по триста јањаца,/ја сам свако по овци познавô (130). Често Милош кроз прозор погледа,/ не би л’ мого̂ кога угледати (191). Немир ми стискоิ уморене груди (Илић, 8). Ромула вечни град спокојно, тихо је дремо̂ (26). Што нас је бригом сламо̂ (29). Ах, мили друзи! Беше дан,/ У ком сам и ја снево̂, /Ал' час је куцно̂, - мину сан (30). Немирни дан je синô (33). За кршне кланце он је слушо̂ можда./Али по њима није ишо̂ сам (45). Једном сам видоิ, цветак млад (83).

\section{a2) -â (само од -ao)}

Тако је јак глас имâ (Матавуљ, 3). Па̂ и уломија ногу (3). Није ми, валај, жа̂ шта сам га убија (4). Јесам ли ја река̂ шта рђаво (18). Ово је синовац Наћварев, али се, госпе ми, није на њ уврга̂. Он је јуче приплива̂ рику на коњу (82).

\section{б) именице}

\section{б1) -оि (од -ао, нпр. мисао, -ео, нпр. анђео и -оо, нпр. до)}

И да моја мисоิ никад не залута (Дучић, 170). То беше анђ̂ неспокојства мог (Илић, 23). А кад је свршио посо̂, он рече спокојно тада (63). И шта ли значи смисо̂ њен? (78) Јато се врана с криком диже/ У опустели, тихи ц̂( (85). И с грактањем орô сури узвија се и шестари (109). И пето̂ запева јасно (336).

\section{б2) $-\hat{a}^{7}($ само од $-a o)$}

Реци му да је његов поса̂ и његова корист (Матавуљ, 34).

\section{в) придеви (од -ао, нпр. светао и -ео, нпр. весео)}

И весоิ лети светом свуд (Илић, 17). Ил каткад само тек звиждање јасно се чује/ и тежак, промукоิ глас (54). Фркће окисоิ коњиц/ И журно у село граби (137). Љубишин призрак ветоิ, млад,/ Спокојно, тихо блуди (219).

${ }^{6}$ Мада смо очекивали да дистинкција између два хомонима буде истакнута дугосилазним акцентом (по̆ - „патос” и под - предлог; ка̂д - „оно што се кади” и кӓд - везник или прилог; ненаглашени облик заменице ми (нас) и наглашени (на̂с)), у сва три случаја употребљен је генитивни знак (пôd, ка̂d, на̂c).

${ }^{7}$ Посебан тип било би сажимање самогласника $a а$ настало губљењем сугл. $x$ : Није тама ода зла времена,/већ је тама од пра̂ пушчанога (Ђурић, 862). 
г) поредбени везник као

г1) коิ (од - $а о)$

Ноћ, и ту се спава... А $\underline{\text { к0 }}$ сабласт чудна,/Међ гробљем и селом још кривуда стаза (Дучић, 7). Њен је корак био/ Кô корак самоће, нечујан и сетан (8). Глас њезин беше к0̂ музика туге (12). У тој мртвој ноћи пали су на воду,/Кô олово мирну и сиву, у мраку (17). Увенуће младо доба, / К̂ што вене росно цвеће (Илић, 10). И с чудне среће, јада мог,/ К̂ㅇ љупки, мили дан,/Весело игра млади бог (17). Шта се ту голицате, ко̂ неке жене (Видојковић 2014: 20).

\section{г2) ка̂ (од -ao)}

Ми смо свате уходили дивно:/ка̂ да бјеше Краљевића Марка,/ма не бјеше коња Марковога;/ка̂ да бјеше војевода Јанко,/ма не бјеше коња Јанковога;/ка̂ да бјеше Старина Новаче,/ма не бјеше коња Новакова;/ка̂ да бјеху два Подреновића,/ма немаше коња̂ њиховијех; 스 да бјеше Бановић Секула,/ма немаше коња Секулова;ㄸâ да бјеше дијете Грујица,/ма немаше коња Грујичина (Ђурић, 34).

\section{Огрешења}

1. Анализа примера показала је да се огрешења о норму своде на:

1) употребу генитивног знака мада нема дилеме о ком облику је реч

2) писање апострофа уместо генитивног знака

3) изостављање генитивног знака онда када је он потребан

1) Прво огрешење представља употребу генитивног знака без обзира на то што постоје детерминатори испред генитива множине или је из контекста јасно да то није облик једнине или неки други падеж (нпр. номинатив):

a) То је било од острига̂ (Кристи 2014: 32). Стеван је могао бити изданак било ког индијанског племена - да није жена̂, које су га привлачиле (Олујић 2010: 246). Ове су речи наше велеузвишене господе бискупа̂ из Мејнота (Џојс 2016: 229). Претворио се у станиште перача прозора, ниских чела̂ и мутна погледа (Великић 2016: 263).

б) у радном глаголском придеву у мушком роду глагола убости:

Лупнуо се нечим, убô се на нешто (Данојлић 1983: 109).

в) у прилогу за количину пола

А тачно у по̂ лета би посао довршен (Андрић 2002: 68).

У случају огрешења под а) огрешења су вероватно проистекла из погрешног тумачења лектора да је неопходно увек користити генитивни знак када је у питању именица чији је наставак у генитиву множине једнак наставку у генитиву једнине, односно када је генитив множине једнак номинативу једнине. Међутим, у сва четири примера читалац не би био у дилеми јер испред именице острига стоји предлог од уз који је именица увек у генитиву (од ос- 
триге/острига), док је за именицу жена јасно да је у множини, што потврђује облик предиката (су привлачиле) и множински облик упитно-односне заменице (које). У следећем примеру генитивни знак није било потребно писати јер су у питању синтагме у којима је збирна именица господа, која конгруира с именицом у генитиву множине, као што је у другој реченици употребљен придев низак такође у множинском облику. У случају под б) у радном глаголском придеву глагола $у б о с т u^{8}$ у мушком роду дошло је до регуларног сажимања самогласника као последице алтернације л:о (убол > убоо > убо), дакле као нормиране алтернације која се врши нпр. код именица као што су во (вол > воо > во $),$ сто $($ стол > стоо > сто $)$, соко (сокол > сокоо > соко) и сл., у којима не користимо генитивни знак.

2) Други случај у коме се сажимање вокала бележи као изостављање самогласника, што се истиче апострофом на основу Правописа из 1993, било је прихватљиво (ипак као лошије решење) и то само у време важења тог правописа. Још је С. Новаковић у својој граматици, посветивши један њен велики део правописним инструкцијама, управо користио апостроф у овим случајевима.

За нас су овде важна огрешења која налазимо у примерима из књижевности и то у поезији и преводној књижевности из периода пре и после Правописа из 1993.

До срца ми је допир’о тај крик (Шекспир 1962: 14). Али час је дош’o (15). Ја сам оставио владу брату свом/ и повук’o се од државе (18). Ти би на исти начин могао/ послати у вечни сан овог старкељу,/тог господина мудрицу, да не би/ осуђив’о наше дело (65). Да одлетим, спречити ме нико не би мог’o (Џојс 2016: 28). Морила га жеђ, а није мог’o да је свлада (234). Мада му је велики Владимир могуће замерио што је добро покис'о на оној војној паради (Блиц, 8. 7. 2017, 5). Б92 је, да не дужим причу - пук’o (Време, 28. 12. 2017, 14). Навик’0 сам да смрти гледам у очи (Михаиловић 2017: 29). „Стиг’o сам”, рекао је (93). Сто пута нам је из добро постављене заседе побег’o (324).

У варијанту овог типа огрешења сврстаћемо и недоследност у употреби генитивног знака у оквиру једног издања.

${ }^{8}$ И са другим префиксима: забости, избости, набости, пробости (исто и са глаголима затрети - затро, продрети - продро и сл.). Други тип огрешења о норму јесте решење са удвојеним самогласником $o$ : Дел Бој мисли да је убоо прави договор када је купио платформу (Недељник, 11. 9. 2017, е-издање). Њега је прошлог четвртка у учионици школе скалпелом убоо осмогодишњи вршњак А. Д. (Политика експрес, 21. 6. 1998, 12). 


\begin{tabular}{|c|c|c|c|}
\hline \multicolumn{4}{|c|}{ (Станковић Шошо, Костић 2016) } \\
\hline решење & КОิ & К’О & КО \\
\hline \multirow{3}{*}{ пример } & $\begin{array}{c}\text { Нек је румен ко̂ } \\
\text { ружа румена... } \\
\text { (стр. 48) }\end{array}$ & $\begin{array}{c}\text { Велика је пола хвата, } \\
\text { А сјаји се к`о од злата. } \\
\text { (стр. 89) }\end{array}$ & $\begin{array}{c}\text { Два комбајна } \\
\text { ко два слона... } \\
(116)\end{array}$ \\
\hline
\end{tabular}

\begin{tabular}{|c|c|c|}
\hline \multicolumn{2}{|c|}{ (Михаиловић 2017) } \\
\hline решење & пос'о & посоิ \\
\hline пример & $\begin{array}{c}\text { И ја радим исти пос'о ко ви! } \\
(83)\end{array}$ & $\begin{array}{c}\text { Ви морате да оставите } \\
\text { сав тај посоิ. (338) }\end{array}$ \\
\hline
\end{tabular}

3) Последње огрешење представљале би ситуације у којима је генитвни знак/знак дужине потребан и то не само због разумљивости садржаја реченице, већ и због њеног ритма, нпр.:

Кад је била у групи са другим девојчицама, ја сам, ноторни индивидуалац, ишао сам, пешке (Грас 2007: 62).

4) Коначно, један вид огрешења јесте употреба генитивног знака уместо акцента, којим такође истичемо значењску разлику. Пример за то био би нам прилог за количину пола и именица део у генитиву једнине:

А тачно у по̂ лета би посао довршен (Андрић 2002: 68). Схватио сам после неколико дана да нећу волети да говорим о овом деิлу свог живота (Ками 1989: 81).

Наиме, у првом случају, које такође представља сажимање, Белић користи дугосилазни акценат (Белић 1934: 171), што налазимо и у Матичином издању из 2010 (пô = пола; 2010: 411). У овом скраћеном облику, прилог пола се употребљава у устаљеним експресивним конструкцијама типа ни по јада, y по ноћи /(бела) дана, ни по јада или код ијекаваца у разговорном језику нпр. пођи по сата раније, па је било какав знак непотребан, тим пре што је сажимање необележено по правилу у количинским изразима типа два и по (дана/недеље/месеиа/литра и сл.). У другом случају, уместо генитивног знака, чије место увек мора бити на последњем слогу, значењску разлику између именица дёо и дёло правимо акцентом, нпр. о овом де́лу свог живота... (им. део) : о овом дёлу свог живота... (им. дело). 


\section{4. ЗАКЉУЧНА РАЗМАТРАЬА}

1. Систематизовање типова огрешења важно је ради анализе самог правописног правила. Наиме, на основу супстандардних одступања у пракси и њиховог броја, нормативисти треба да виде у ком правцу би требало да се крећу евентуална побољшања конкретног правописног правила. Наравно, супстандардна огрешења не могу бити нормативно прихватљива уколико нису у складу с постојећим правилима. Ипак, у случају генитивног знака/знака дужине могуће су извесне корекције.

2. Прва корекција у вези је са бројем случајева у којима треба користити генитивни знак. Могло би се задржати истицање дистинкције између облика генитива множине и неког облика једнине, са прецизном инструкцијом да се дати знак користи искључиво изнад последњег самогласника (на крају речи), док би сажимање вокала и разликовање акцентованих од неакцентованих хомонимних речи било бележено другачије.

3. Иако је дужина обележеног самогласника оно што повезује све случајеве употребе овог знака, видели смо да се на основу броја огрешења (у односу на актуелну норму) у вези са означавањем супстандардног лика глаголског придева радног овај случај у пракси доживљава и као неписање/неизговарање једног од два самогласника у додиру. Овај случај разликује се од осталих и у томе што представља супстандардни облик. Ову врсту сажимања вокала, коју по актуелној норми можемо (али не морамо) означити генитивним знаком, могли бисмо обележити употребом апострофа - што и није новина, јер ју је предлагао и у тој позицији користио Стојан Новаковић, а, додуше као треће решење, налазимо га и у Правопису из 1993. И за кориснике би то било разумљивије јер би у истом тексту имали једнако решење, а апостроф би био и ознака да је дати облик, иначе веома чест у пракси, супстандардан ${ }^{9}$, на шта се употребом генитивног знака не указује, што опет мислимо да је врло важно. Тако се на исти начин бележе сажети облици глагола у футуру I (ћe каз 'ти), презенту (мож'), императиву (поклон'те се), аористу (разблажи' ce). Правило о употреби апострофа за обележавање сажетих вокала у радном глаголском придеву (типа рек'о/река') било би проширено и на именице (типа

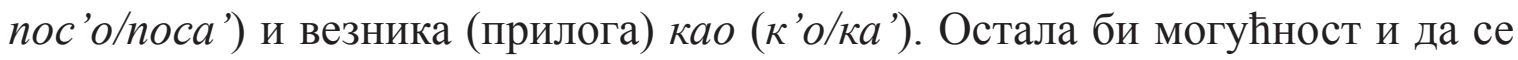
то сажимање и не бележи (дошо, ко, река), али у текстовима у којима таквих примера има више (жаргонски или дијалекатски говор). Коначно, тако бисмо стандардизовали велики број примера у актуелној пракси ${ }^{10}$.

\footnotetext{
${ }^{9}$ Брборић 2011: 91.

${ }^{10}$ Најсвежији примери јесу наслов новог филма у нашим биоскопима („Стиг’o ћале 2”, децембар 2017) и књига Д. Михаиловића Злотвори (издање 2017) са примерима Мог’о сам да узмем кифлу (Михаиловић 2017, 15). Док ви бирате поса', избије побуна (82). И ја радим исто пос'о к’о ви (83).
} 
4. И треће решење које се односи на употребу генитивног знака у актуелном правопису могло би се кориговати. Наиме, удвајање двеју речи од којих је једна акцентована а друга не или њихово разликовање било би обележено управо акцентом речи која може бити акцентована - с јасно наглашеним принципом доследности, али и функционалности (што би значило да се нпр. презент глагола дати у 3. л. јд. не акцентује увек (непотребан је у примеру $O н$ не да оловку; што би била инструкција намењена лекторима)).

5. Друга корекција тицала би се терминологије. Избор терминолошког решења повезан је са бројем случајева у којима бисмо бележили овај знак. Наиме, за назив знак дужсине раније се определио Шипка (Шипка 2008: 36) и он већ постоји у неким правописним приручницима заједно са називом генитивни знак или самостално. Ипак реч је о два знака која су графички различита. ${ }^{11}$ Други назив генитивни знак или, још боље, знак за генитив множине (Брборић 2016: 157) одговарао би у потпуности уколико бисмо број случајева у којима би се овај знак бележио свели управо само на разликовање облика генитива множине од неког облика једнине, као што смо ми то предложили. У правописној (и шире, граматичкој, језичкој) терминологији терминолошко двојство може бити оправдано ако за то постоје разлози, било да је реч о традицији или о лингвистичкој оправданости. У случају актуелног двојства у називу за знак ”, мислимо да тих разлога више нема, те да би давање предности једном називу у односу на други било пре свега целисходно имајући у виду правописну праксу, а тиме бисмо избегли и покушај стварања новог термина (нпр. разликовни знак/знак разлике).

\section{ИЗВОРИ}

Андрић 2002: Иво Андрић, Мост на Жепи, Најлепше приповетке Ива Андрића, Београд: Просвета.

Атанацковић 2017: Дејан Атанацковић, Лузитанија, Београд: Бесна кобила.

Блиц, 8. 7. 2017, 5.

Бугарски 2005: Ранко Бугарски, Језик и култура, Библиотека XX век, Београд: Чигоја штампа.

Великић 2016: Драган Великић, Иследник, Београд: Лагуна.

Велмар Јанковић: Светлана Велмар Јанковић, Дорћол, www.ask.rs.

Видојковић 2014: Марко Видојковић, Уредник, Београд: Лагуна.

${ }^{11}$ У Хрватском правопису за обележавање генитива множине користи се знак дужине (занагласна дужина): Остао је без пријатеља̄ (ХП2013:112). 
Време, 28. 12. 2017, 14.

Грас 2007: Гинтер Грас, Љуштећи лук, Београд: Народна књига - Алфа, превод Зоран С. Цветковић.

Данојлић 1983: Милован Данојлић, Змијин свлак, Београд: Нолит.

Десница 1963: Владан Десница, Прољећа Ивана Галеба, Београд: „Бранко Ђоновић”.

Дучић: Јован Дучић, Песме, www.ask.rs.

Ђурић: Војислав Ђурић, Антологија народних јуначких песама, www.ask.rs.

Еренрајх Остојић 2000: Максимилијан Еренрајх-Остојић, Карактеристика, Београд: Рад.

Игњатовић: Јаков Игњатовић, Вечити младожењ $а$, www.ask.rs.

Илић: Војислав Илић Млађи, Песме, www.ask.rs.

Ками 1989: Албер Ками, Странаи, Београд: Просвета, превод Зорица ХаџиВидојковић.

Кристи 2014: Агата Кристи, Карипска загонетка, Београд: Младинска књига, превод Владимир Д. Јанковић.

Матавуљ: Матавуљ, Симо, Бакоњ $а$ Фра Брне, www.ask.rs.

Михаиловић 2017: Драгослав Михаиловић, Злотвори, Београд: Лагуна.

Мураками 2017: Харуки Мураками, O чему говорим кад говорим о трчању, Београд: Геопоетика, превод Дивна Глумац.

Недељник, 11. 9. 2017, е-издање:

http://www.nedeljnik.rs/magazin/portalnews/izgubljena-epizoda-mucki-biceprikazana-posle-33-godine/ Посећено 1. 12. 2017.

Ненадић: Добрило Ненадић, Доротеј, www.ask.rs.

Ненадовић: Матеја Ненадовић, Мемоари, www.ask.rs.

Олујић 2010: Гроздана Олујић, Гласови у ветру, Београд: Српска књижевна задруга.

Пекић 1995: Борисав Пекић, Атлантида I-II, Нови Сад: Соларис.

Политика експрес, 21. 6. 1998, 12.

Селенић 1997: Слободан Селенић, Убиство с предумишљајем, Београд: Просвета. 
Станковић Шошо/Костић: Наташа Станковић Шошо, Маја Костић, Уз речи растемо, читанка за други разред основне школе, Београд: Логос, 2016.

Ћосић: Добрица Ћосић, Корени, www.ask.rs.

Црњански: Мирослав Црњански, Сеобе и Друга књига Сеоба, www.ask.rs.

Џојс 2016: Џејмс Џојс, Уликс, Београд: Геопоетика, превод Зоран Пауновић.

Шекспир 1962: Вилјем Шекспир, Бура, Веселе жене виндзорске, Београд: Просвета, превод Живојин Симић, Сима Пандуровић.

\section{ЛИТЕРАТУРА}

Белић 1923: Александар Белић, Правопис српскохрватског књижевног језика, Београд: Издавачка књижарница Геце Кона.

Белић 1952: Александар Белић, Правопис српскохрватског књиюевног језика, Београд: Просвета.

Брборић 2011: Вељко Брборић, Правопис и школа, Београд: Друштво за српски језик и књижевност Србије.

Брборић 2016: Вељко Брборић, О српском правопису, Београд: Друштво за српски језик и књижевност Србије.

Брборић 2017: Вељко Брборић, Српска правописна терминологија данас - у науци и настави, у: Предраг Пипер, Владан Јовановић (ур.), Словенска терминологија данас, Београд: Српска академија наука и уметности.

Даничић 1850: Ђура Даничић, Мала српска граматика, Беч: Штампарија Јерменског манастира.

Дешић 2015: Милорад Дешић, Правопис српског језика, школско издаъе, Београд: Klett.

Јерковић/Вујовић 2012: Јован Јерковић, Душанка Вујовић, Школски правопис српскога језика, Београд: Школа плус.

Кликовац 2017: Душка Кликовац, О знаковима у правопису (1): подела на реченичне и нереченичне и одговарајућа терминологија, Научни састанак слависта у Вукове дане, 46/3, 95-111.

Новаковић 1902: Стојан Новаковић, Српска граматика, Београд: Државна штампарија. 
Пешикан et al. 1993: Митар Пешикан, Јован Јерковић, Мато Пижурица, Правопис српскога језика. Нови Сад: Матица српска.

Пешикан et al. 2010: Митар Пешикан, Јован Јерковић, Мато Пижурица, Правопис српскога језика. Нови Сад: Матица српска.

Пипер/Клајн 2013: Предраг Пипер, Иван Клајн, Нормативна граматика српског језика, Нови Сад: Матица српска.

Правопис 1960: Правопис српскохрватскога књижевног језика са правописним речником (израдила правописна комисија), Нови Сад - Загреб: Матица српска - Матица хрватска.

Симић et al. 1993: Радоје Симић, Живојин Станојчић, Бранислав Остијић, Божо Ћорић, Милош Ковачевић, Правопис српскога језика са речником, Никшић - Београд: Унирекс - Штампа.

Симић 2016: Радоје Симић, Српски правопис, Београд: Научно друштво за неговање и проучавање српског језика - Јасен.

Станојчић/Поповић 2008: Живојин Станојчић, Љубомир Поповић, Граматика српскога језика, уџбеник за гимназије и средње школе, Београд: Завод за уџбенике.

Стевановић 1991: Михаило Стевановић, Савремени српскохрватски језик (Граматички системи и књижевнојезичка норма), Београд: Научна књига.

Чутурило 1884: Стево Чутурило, Српски правопис за школску употребу, Панчево.

Хрватски правопис 2013: Жељко Јозић et al., Хрватски правопис, Загреб: Институт за хрватски језик и језикословље.

Шипка 2008: Милан Шипка, Стандарднојезичка преиспитивања 1, Нови Сад: Прометеј.

Шипка 2011: Милан Шипка, Култура говора, Нови Сад: Прометеј.

\section{THE GENITIVE SIGN OR LENGHT SIGN}

\section{Summary}

In this paper, the author analyzes the distribution restrictions of the use of the genitive sign and studies the justification of the terminological duality resulting from the parallel use of the two terms - the genitive sign and the length sign. The analysis covered all the relevant normative handbooks, starting with Belić's orthography, through Matica srpska's 
editions to Dešić's and Simić's orthography handbooks. In addition, a large number of examples deviate from the current norm. A solution is also proposed by which the rule would be whether this sign is used only when we do not distinguish forms of plural genitives and a form of singularity.

Key words: genitive sign, length sign, orthography, grammar

Goran N. Zeljić 